\title{
Detection of early effects of a single herbicide (diuron) and a mix of herbicides and pharmaceuticals (diuron, isoproturon, ibuprofen) on immunological parameters of Pacific oyster (Crassostrea gigas) spat
}

\author{
A. Luna-Acosta ${ }^{a, c,{ }^{*},}$ T. Renault ${ }^{b, c, ~}{ }^{*}$, H. Thomas-Guyon ${ }^{a, c}$, N. Faury ${ }^{b, c}$, D. Saulnier ${ }^{b, c, 1}$, H. Budzinski ${ }^{d}$, \\ K. Le Menach ${ }^{d}$, P. Pardon ${ }^{d}$, I. Fruitier-Arnaudin ${ }^{a, c}$, P. Bustamante ${ }^{a, c}$
}

\begin{abstract}
a Littoral Environnement et Sociétés (LIENSs), UMR 7266, CNRS-Université de La Rochelle, 2 rue Olympe de Gouges, F-17042 La Rochelle Cedex 01, France

${ }^{\mathrm{b}}$ Ifremer, Laboratoire de Génétique et Pathologie (LGP), Ronce-les-Bains, 17390 La Tremblade, France

${ }^{c}$ Fédération de Recherche en Environnement pour le Développement Durable (FR 3097), 2 rue Olympe de Gouges, F-17 042 La Rochelle Cedex 01, France

d Université Bordeaux 1-CNRS, EPOC, Laboratoire de Physico-Toxico-Chimie de l'environnement (LPTC), UMR 5805, 351 Cours de la Libération, 33405 Talence, France ${ }^{1}$ Present address: Laboratoire Biotechnologie et Qualité de la Perle, Centre Océanologique du Pacifique, Ifremer,
BP 7004, 98719 Taravao, French Polynesia.
\end{abstract}

\author{
*: Corresponding authors : A. Luna-Acosta, Tel.: +33 (0)5 46507623 ; fax: +33 (0)5 46507663 ; \\ email address : aluna1508@yahoo.com; T. Renault, Tel.: +33 546762610 ; fax: +33 546762611 ; \\ email address : trenault@ifremer.fr
}

\begin{abstract}
:
In the context of massive summer mortality events of the Pacific oyster Crassostrea gigas, the aim of this study was to investigate the early effects on genes, enzymes and haemocyte parameters implicated in immune defence mechanisms in C. gigas oysters exposed to a potentially hostile environment, i.e. to an herbicide alone or within a mixture. Following $2 \mathrm{~h}$ of exposure to the herbicide diuron at $1 \mathrm{\mu g} \mathrm{L}^{-1}$, the repression of different genes implicated in immune defence mechanisms in the haemocytes and the inhibition of enzyme activities, such as laccase-type phenoloxidase (PO) in the plasma, were observed. The inhibition of superoxide dismutase (SOD) activity in the plasma was also observed after 6 and $24 \mathrm{~h}$ of exposure. In the mixture with the herbicides diuron and isoproturon, and the pharmaceutical ibuprofen, catecholase-type PO activity in the plasma and the percentage of phagocytosis in the haemocytes were reduced after $6 \mathrm{~h}$ of exposure. Our results showed that early effects on molecular, biochemical and cellular parameters can be detected in the presence of diuron alone or within a mixture, giving an insight of its potential effect in situations that can be found in natural environments, i.e. relatively high concentrations for short periods of time.
\end{abstract}

\section{Highlights}

- Crassotrea gigas spats were exposed to an herbicide alone or within a mixture. In vivo exposures were done with relatively high concentrations of contaminants. Experiments were carried out for short periods of time. Early effects on molecular, biochemical and cellular parameters were detected. Diuron alone or within a mixture may potentially affect immune defences in oysters.

Keywords: Bivalve ; Pollution ; Gene expression ; Laccase ; Superoxide dismutase ; Phagocytosis 


\section{Introduction}

Estuaries are among the most ecologically and economically productive environments in the world, by serving as feeding grounds for migratory waterfowls, as nurseries for juvenile fish and invertebrate larvae, and by providing shelter for many types of benthic organisms (Johnston 1981). Among important species inhabiting these zones, the Pacific oyster Crassostrea gigas is the leading aquaculture product at the worldwide level (FAO 2010). However, high mortalities of this species have been observed in summer, in many regions of the world, and especially on the French coasts (Samain et al. 2007). It has been suggested that these mortality events are related to a weakening of C. gigas immune defences (Cheney et al. 2000), probably caused by multiple factors, including aquaculture practices, temperature variations, physiological stress, and the presence of pathogens and contaminants in the environment.

Aquatic coastal habitats are particularly subject to contamination by herbicides, via runoff, leaching, spray drift or accidental spills. The most widely used herbicides in agriculture are substituted urea herbicides, such as diuron or isoproturon (Barbash 1999). These herbicides are also used as algicides in paints and coatings, and in the case of diuron, concentrations up to $6.7 \mathrm{\mu g} \mathrm{L}^{-1}$ have been found in coastal waters (Thomas et al. 2001). Due to its toxicity, the use of diuron has been forbidden by French laws since 2008. However, a recent study reported the presence of diuron in French aquatic environments, confirming its persistence despite restriction policies (Pesce et al. 2010).

Diuron and other herbicides such as isoproturon and atrazine may exert an effect on immune parameters of $C$. gigas at the molecular, biochemical, and cellular levels (Tanguy et al. 2005, Bouilly et al. 2007, Gagnaire et al. 2007). Additionally, nonsteroidal anti-inflammatory drugs (NSAIDs), such as ibuprofen, have been detected at concentrations reaching up $1.3 \mathrm{\mu g} \mathrm{L}^{-1}$ in wastewater treatment plant (WWTP) effluents and in marine seawater samples (Rabiet et al. 2006, Togola \& Budzinski 2008) where herbicides have been found at high concentrations, suggesting that experimental approaches with toxicant mixtures are needed (ASCI ENCE 2005). Nevertheless, very little is known on the toxic effects of pharmaceuticals such as ibuprofen on marine bivalves (Gagne et al. 2004, 2006, Ericson et al. 2010).

In this general context, the aim of this work was to study the short-term responses on immune parameters of $C$. gigas spat in experimental conditions at molecular (gene expression), biochemical (enzymatic levels) and cellular (cellular mortality and phagocytosis activity) levels, by exposing oysters (i) to diuron at nominal concentration (nc) of $1 \mu \mathrm{g} \mathrm{L}^{-1}$ for $24 \mathrm{~h}$, and (ii) to a mixture of two herbicides and one pharmaceutical, i.e. diuron $\left(n c=5 \mu \mathrm{g} \mathrm{L}^{-1}\right)$, isoproturon $\left(\mathrm{nc}=5 \mu \mathrm{g} \mathrm{L}^{-1}\right)$ and ibuprofen $\left(\mathrm{nc}=5 \mu \mathrm{g} \mathrm{L}^{-1}\right)$.

\section{Materials and methods}

\subsection{Oysters}

Pacific oyster (Crassostrea gigas) spat, less than 1 year old, known to be generally more sensitive to environmental stress than adults (Perdue et al. 1981), were purchased from commercial shellfish nursery located in Vendée (France). Oysters were acclimatized in the laboratory at $19 \pm 1{ }^{\circ} \mathrm{C}$ during two weeks before starting experiments. This temperature was selected because, during summer mortality events, 
water temperatures are often over a value of $19{ }^{\circ} \mathrm{C}$ (Gagnaire et al. 2007). Animals were fed daily with $5.10^{4}$ cell $\mathrm{mL}^{-1}$ of Heteroskeletonema sp. (Bacillariophyceae).

\subsection{Contaminants}

All chemicals were purchased from Sigma-Aldrich, France, unless specified. Stock solutions of diuron (1-[3,4 dichlorophenyl]-3,3-dimethyl urea) and isoproturon (3-[4isopropylphenyl]-1,1-dimethylurea) were prepared in ethanol $80 \%$. Stock solution of ibuprofen (a-methyl-4-[2-methylpropyl]-benzenacetic acid) was prepared in ultra pure quality water (Milli-Q). Diuron, isoproturon and ibuprofen were added to the tanks in the form of diluted solutions allowing spikes of small volumes. All the experiments were conducted under dark conditions to avoid photodegradation of the chemicals (Shankar et al. 2008).

\subsection{Experimental design}

\subsubsection{Experiment conducted with diuron at $1 \mu \mathrm{g} \mathrm{L-1}$}

Two groups of 70 oysters were exposed in $35 \mathrm{~L}$ tanks to diuron $\left(\mathrm{nc}=1 \mu \mathrm{g} \mathrm{L}^{-1}\right)$ for a period of $24 \mathrm{~h}$ and under dark conditions. The concentration used was selected according to concentrations reported in the literature (Heberer 2002). Two tanks containing 70 oysters maintained in $35 \mathrm{~L}$ clean aerated seawater were used as control experiment. The experiment was repeated three times.

\subsubsection{Experiment conducted with diuron, isoproturon and ibuprofen}

Two groups of 70 oysters were exposed in $35 \mathrm{~L}$ tanks to a cocktail of diuron (nc $=5 \mu \mathrm{g}$ $\left.\mathrm{L}^{-1}\right)$, isoproturon $\left(\mathrm{nc}=5 \mu \mathrm{g} \mathrm{L}^{-1}\right)$ and ibuprofen $\left(\mathrm{nc}=5 \mu \mathrm{g} \mathrm{L}^{-1}\right)$. The concentrations used were selected based on the fact that concentrations up to $6.70 \mu \mathrm{g} \mathrm{L}^{-1}$ and $9.89 \mathrm{\mu g} \mathrm{L}^{-1}$ of phenylurea herbicides and NSAIDs have been detected in aquatic environments, respectively (Thomas et al. 2001, Rabiet et al. 2006, Togola \& Budzinski 2008). Two tanks containing 70 oysters maintained in $35 \mathrm{~L}$ clean aerated seawater were used as control experiment. Animals were exposed for $6 \mathrm{~h}$ under dark conditions. The experiment was repeated four times.

\subsection{Sampling procedures}

\subsubsection{Seawater sampling}

For each trial, $50 \mathrm{~mL}$ of seawater were collected in one of the two contaminated tanks, at 0 and $24 \mathrm{~h}$ in trials conducted with diuron, and at $0,1,3$ and $6 \mathrm{~h}$, in trials conducted with diuron, isoproturon and ibuprofen.

\subsubsection{Haemolymph collection}

After carving a small notch in the dorsal shell of the oyster, $\sim 0.3-0.5 \mathrm{~mL}$ of haemolymph were withdrawn from the adductor muscle sinus with a $1 \mathrm{~mL}$-syringe equipped with a needle $(0.9 \times 25 \mathrm{~mm})$. Haemolymphs from 10 oysters from each of the two exposure tanks were pooled to obtain a sufficient volume. In this respect, one pool corresponds to the haemolymph of 20 oysters, with 10 oysters collected per tank. 
Haemolymph samples were filtered through a $60 \mu \mathrm{m}$ mesh to eliminate aggregates and then kept on ice to avoid enzymatic degradation.

First, $400 \mu \mathrm{L}$ of haemolymph from each pool was used immediately to study cell mortality and phagocytosis activity by flow cytometry. Then, $600 \mu \mathrm{L}$ of haemolymph was centrifuged $\left(260 \times \mathrm{g}, 10 \mathrm{~min}, 4^{\circ} \mathrm{C}\right)$ and the acellular fraction (supernatant) was frozen at $-80^{\circ} \mathrm{C}$ until further enzymatic analysis by spectrophotometry.

The remaining haemolymph was centrifuged $\left(1500 \times \mathrm{g}, 10 \mathrm{~min}, 4{ }^{\circ} \mathrm{C}\right)$ and $1 \mathrm{~mL}$ of Trizol $^{\circledR}$ was added to the cell pellets. The mix was frozen at $-80{ }^{\circ} \mathrm{C}$ until further extraction for gene expression analysis.

\subsection{Seawater and oyster contaminant concentrations}

For trials carried out with diuron alone, concentrations of diuron and its metabolite (i.e. 1-[3,4 dichlorophenyl] urea [DCPU]) were determined in the seawater and in a pool of 5 oysters per treatment, at 0,2 and $24 \mathrm{~h}$ of exposure for one experiment. Analyses were performed by the laboratory Idhesa (Brest, France). The detection limit was $0.02 \mu \mathrm{g} \mathrm{L}^{-1}$ for water samples, and $0.2 \mathrm{\mu g} \mathrm{kg}^{-1}$ for diuron and DCPU in oyster soft tissues.

For trials conducted with the mixture of contaminants (diuron, isoproturon and ibuprofen), analyses were carried out in two of the four experiment replicates conducted for this study. Contaminants were extracted via solid-phase extraction (SPE), using Oasis HBL (for herbicides) or MCX cartridges (for ibuprofen) and analyzed by $\mathrm{LC} / \mathrm{MS} / \mathrm{MS}$. The analytical procedures were adapted from Alder et al. (2006) for herbicides and from Togola \& Budzinski (2008) for ibuprofen. Detection limits were $0.1 \mathrm{ng} \mathrm{L}^{-1}$ for pesticides and $0.5 \mathrm{ng} \mathrm{L}^{-1}$ for ibuprofen. Pesticides were analyzed using a UPLC/MS/MS system from Waters company (UPLC Acquity system from Waters coupled to a Quatro Premier XE mass spectrometer from Micromass Technologies, Manchester, UK; mobile phase: water ( $5 \mathrm{mM}$ ammonium acetate $+0.1 \%$ acetic acid) / methanol (100\% / $0 \%$ to $0 \% / 100 \%$ within 17 minutes at $0.5 \mathrm{~mL}$ min-1); column: Kinetex C18 $100 \mathrm{~mm} \times 2.1 \mathrm{~mm} \times 1.7 \mathrm{~mm}$. The ionization mode was positive atmospheric pressure chemical ionization for all analytical compounds. Agilent (Palo Alto, CA, USA) supplied the 1100 Series HPLC system connected to a quadrupole 1100 mass spectrometer for ibuprofen analyses; mobile phase: water / acetonitrile ( $100 \% / 0 \%$ to $0 \% / 100 \%$ within 30 minutes at $\left.0.6 \mathrm{cc} \mathrm{min}^{-1}\right)$; column: Zorbax SBC18 50 $\mathrm{mm} \times 2.1 \mathrm{~mm} \times 1.8 \mathrm{~mm}$.

\subsection{Flow cytometry analysis}

Haemocyte mortality and phagocytosis percentage were analyzed with an EPCIS XL 4 (Beckman Coulter) flow cytometer as previously described (Gagnaire et al. 2006). For each sample, 3000 events were counted.

\subsection{Enzymatic analysis}

Catecholase-type and laccase-type PO activities were determined as described previously (Luna-Acosta et al. 2010), by using domapine and p-phenylenediamine (PPD) as substrates, respectively. One unit of catecholase or laccase activity corresponds to the amount of enzyme that catalyzes the formation of 1 umole of 
product per minute. SOD activity was determined by the method described by Therond et al. (1996). One unit of SOD is defined as the amount of enzyme that promotes a 50 $\%$ decrease in the rate of INT reduction.

All enzyme activity assays were carried out in triplicate for each sample and were expressed in relation to protein concentration measured according to the Lowry method with slight modifications, by using bicinchoninic acid and copper sulphate 4\% (Smith et al. 1985). Serum albumin was used as standard.

\subsection{Oyster gene expression in haemocytes}

Seven immune-related genes previously identified from C. gigas cDNA database were selected, i.e. multicopper oxidase (laccase), macrophage expressed protein 1-like protein (Mpeg1), myeloid differentiation factor 88 (MyD88), superoxide dismutase (SOD), lipopolysaccharide-binding protein/mammalian bactericidal/permeabilityincreasing protein (LBP/BPI), tissue inhibitor of metalloproteinases (TIMP) and lysozyme. As a housekeeping gene, the Elongation factor I (EF I) gene was used as reference.

Samples were treated with the RQ1 RNase-free DNase (Promega) to remove DNA. The quality of extracted RNA was checked on 1\% agarose gel. RNA concentrations and purity were measured by absorption spectrophotometry $\left(A_{260 \mathrm{~nm}}\right)$.

Reverse transcription (RT) of extracted haemocyte RNA (500 ng) was carried out by using SuperScript ${ }^{\mathrm{TM}}$ III Reverse Transcriptase kit (Invitrogen), and following manufacturer's recommendations. The relative levels of gene transcripts were investigated by real-time PCR using a MX3005P® Stratagene. cDNA were diluted at $1 / 30$ with sterile ultra pure quality water before use.

Real-time PCR was performed in triplicates and as described previously (Bado-Nilles et al. 2010). The cycling conditions consisted of Taq polymerase thermal activation (10 min, $95^{\circ} \mathrm{C}$ ) followed by 40 cycles of denaturation $\left(30 \mathrm{~s}, 95^{\circ} \mathrm{C}\right)$, annealing $(1 \mathrm{~min}, 60$ ${ }^{\circ} \mathrm{C}$ ) and elongation $\left(1 \mathrm{~min}, 72^{\circ} \mathrm{C}\right)$. Finally, a melting curve of PCR product $\left(60-95^{\circ} \mathrm{C}\right)$ was performed to ensure the production of a single specific product.

The relative mRNA expression ratio for a considered gene was based on the PCR efficiency $(E)$ and the cycle threshold $(C t)$ of the treated samples versus the untreated samples (control) expressed in comparison to the reference gene (EF I) as described previously (Pfaffl 2001).

$$
\text { Ratio }=\frac{(\text { E studied gene })^{\Delta \mathrm{Ct} \text { studied gene(untreated-treated) }}}{(\text { E reference gene })^{\Delta \mathrm{Ct} \text { reference gene(untreated-treated) }}}
$$

\subsection{Statistics}

All values are reported as mean \pm standard deviation (SD). For trials conducted with diuron alone, only two out of the three experiments were taken into account for statistical analysis, because for one of the experiments the temperature in the seawater was at $15 \pm 1{ }^{\circ} \mathrm{C}$ and not at $19 \pm 1{ }^{\circ} \mathrm{C}$, the effects of herbicides differing depending on the seawater temperature (Gagnaire et al. 2007). Statistical analysis was carried out with STATISTICA 7.0. Values were tested for normality (Shapiro test) and homogeneity 
of variances (Bartlett test). In some cases, values were normalized using logarithmic transformations $\left(\log _{10}\right)$ or an $r$ angular arcsinus $\sqrt{ }$ (percentage of positive cells) transformation (in the case of haemocyte parameters), before analysis. For normal values, a two-way nested ANOVA was used, with treatment and time as fixed factors, and pool as random factor. Pool was nested within each combination of treatment and time (Zar 1984). When the null hypothesis $\left(\mathrm{H}_{0}\right.$ : no difference between treatments or within treatment at different time intervals) was rejected, significant differences were tested using Tukey's HSD test. For non normal values, a Kruskal-Wallis test was used, followed by a Dunn's multiple comparisons test. Significant differences were considered at $p<0.05$.

\section{Results and discussion}

It is well known that in natural waters, uneven concentrations of pesticides are found in the seawater mass because of different factors such as seasonal agricultural practices and weathering processes (rainfall, photodegradation, volatilization), and peak concentrations are often found in the coastal environment for short periods of time (Munaron 2004, Samain et al. 2007). However, most of the exposure experiments in oysters have been carried out for relatively long periods of time, i.e. from one week to one month (Tanguy et al. 2005, Bouilly et al. 2007, Gagnaire et al. 2007), giving an insight on effects of chronic exposures on physiological functions, but not on the effects of short-term or pulse exposures (Burgoa \& Wauchope 1995, Buisson et al. 2008). Thus, the aim of this study was to investigate the early effects on genes, enzymes and haemocyte parameters implicated in immune defence mechanisms in $C$. gigas exposed to an herbicide alone or within a mixture, for a short time period.

\subsection{Experiment conducted with diuron $\left(1 \mu \mathrm{g} \mathrm{L}^{-1}\right)$}

In the control tank, diuron was not detected either in seawater or in oyster soft tissues. In the tanks spiked with diuron, oysters were effectively exposed to $0.8 \mu \mathrm{g}$ diuron $\mathrm{L}^{-1}$ and, by the end of the experiment, $21 \%$ of diuron was lost (Table 1 ). If we consider that, from the beginning to the end of the experiment, all oysters possessed $\sim 0.014 \mu \mathrm{g}$

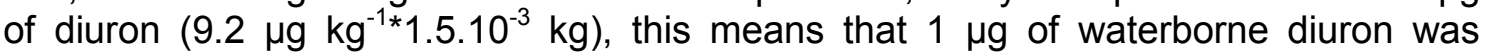
present in all oyster soft tissues $(n=70)$, i.e. $2 \%$ of the initial quantity of dissolved diuron. This suggests that $19 \%$ of the initial quantity of dissolved diuron disappeared by volatilization or adsorption on the tank walls and oyster shells. However, diuron is a strongly hydrophilic molecule and is not volatile (Gramatica \& Di Guardo 2002). Some degradation products of diuron, such as DCPU, have been reported to be more toxic than diuron itself (Giacomazzi \& Cochet 2004). Nevertheless, no traces of DCPU were found in oyster soft tissues in the present study. Thus, the disappearance of diuron in the water column could be explained by a metabolization of diuron by oysters into other compounds than DCPU, such as DCPMU (1-[3,4-dichlorophenyl]-3-methyl urea) or DCA (3,4-dichloroaniline; Giacomazzi \& Cochet 2004), which were not measured in the present study.

As $28 \mu \mathrm{g}$ of diuron $\left(0.8 \mu \mathrm{g} \mathrm{L}^{-1 *} 35 \mathrm{~L}\right)$ was present at the beginning of the study in each contaminated tank, theoretically $0.4 \mu \mathrm{g}$ (i.e. $28 \mu \mathrm{g} / 70$ oysters) were available per oyster. Taking into account the theoretical oyster filtration rate is $1.4 \mathrm{~L}_{\text {osster }}{ }^{-1} \mathrm{~h}^{-1}$ (Table 1), each animal can filtrate $0.4 \mu \mathrm{g} * 1.4 \mathrm{~L} / 35 \mathrm{~L}^{-1} \mathrm{~h}^{-1}=0.016 \mu \mathrm{g}$ of diuron per hour. This result is similar to the quantity of diuron found in oysters at 2,6 and $24 \mathrm{~h}$ of exposure, i.e. $0.014,0.015$ and $0.016 \mu \mathrm{g}$, respectively. In addition, the theoretical quantity of diuron that oysters were able to integrate in $1 \mathrm{~h}$, was found in their soft 
tissues after $2 \mathrm{~h}$ of exposure, demonstrating that diuron is very rapidly bioaccumulated in oyster soft tissues. Interestingly, no significant increase was observed after $24 \mathrm{~h}$ of exposure, suggesting that oysters present a very limited capacity to bioaccumulate diuron at high levels following an exposure from the dissolved phase.

In addition, in the present study, oysters presented a bioconcentration factor (BCF) for diuron of 17. In a previous study, experiments carried out with 21-month-old C. gigas oysters exposed to diuron $\left(1 \mu \mathrm{g} \mathrm{L}^{-1}\right)$, led to an accumulation of diuron of $7.27 \mathrm{\mu g} \mathrm{kg}^{-1}$ wet flesh (Buisson et al. 2008), and to a BCF of $\sim 7$, confirming that a 24 h-exposure is sufficient to detect diuron in oyster soft tissues and that oysters present a low potential to bioaccumulate diuron.

POs are a group of enzymes composed of tyrosinases, catecholases and laccases, the key enzymes of melanisation, known to be implicated on invertebrate immune responses (Söderhäll \& Cerenius 1998). Recently, the presence of catecholase and laccase, but not tyrosinase, activities were demonstrated in C. gigas (Luna-Acosta et al. 2010). In the present study, no significant effects were observed on catecholase activity in oysters exposed to diuron at $1 \mathrm{\mu g} \mathrm{L}^{-1}$ for $24 \mathrm{~h}$, while significantly lower activities were observed for laccase at 2 and $6 \mathrm{~h}$, in comparison to control (decrease of $\sim 40 \%$ and $\sim 50 \%$, respectively; Fig. 1a). The molecule 1-phenyl-2-thiourea (PTU) is known to be a specific inhibitor of all types of POs (Luna-Acosta et al. 2010). Therefore, diuron, a phenylurea herbicide, may act as an inhibitor of laccase activity. In addition, differential effects of diuron in catecholase and laccase activities may be due to differences for these enzymes on sensitivities to inhibitors, as it has been shown for acetylcholinesterases in C. gigas, and their capacity to be insensitive to organophosphate and carbamate inhibitors (Bocquene et al. 1997).

A significant decrease in the activity of the antioxidant enzyme SOD was also observed at 6 and $24 \mathrm{~h}$ of exposure, in comparison to control (decrease of $\sim 15$ and $\sim 30 \%$, respectively; Fig. 1b). In the present study, diuron may generate reactive oxygen species (ROS) and induce an overwhelming of the antioxidant system, as suggested previously (Geoffroy et al. 2002). In addition, these results are in agreement with studies carried out in adult oysters, which revealed that diuron can exert different effects in this marine bivalve, e.g. a transient effect on reproduction (partial spawning) and tissue structure (atrophy of the digestive epithelium) after 1 week of exposure at 1 $\mu \mathrm{g} \mathrm{L}^{-1}$ (Buisson et al. 2008), and on aneuploidy and immune parameters after 4 weeks of exposure at $300 \mathrm{ng} \mathrm{L}^{-1}$ and $3 \mathrm{\mu g} \mathrm{L}^{-1}$ (Bouilly et al. 2007).

Laccase gene was significantly repressed at $2 \mathrm{~h}(0.40 \pm 0.10 ;$ Fig. 2). The overexpression observed at $6 \mathrm{~h}(2.04 \pm 0.29)$, could be an internal response to compensate the underexpression that occurred at $2 \mathrm{~h}$. However, at $24 \mathrm{~h}$ the expression was repressed again $(0.51 \pm 0.33)$, suggesting that overcompensation observed at $6 \mathrm{~h}$ was not sufficient to abolish diuron effects on gene expression. A down-expression of Mpeg1 (0.23 \pm 0.24$)$, LBP/BPI $(0.21 \pm 0.22)$ and TIMP $(0.63 \pm 0.15)$ was also observed after $2 \mathrm{~h}$ of exposure. Since the products of these genes appear as important factors in innate immunity in different species and have been reported in marine molluscs (Mah et al. 2004, Mitta et al. 2005), a down-regulation of these genes may lead to a depletion of the defence activities against pathogens. Similarly to the present study, a downregulation of the LBP/BPI and TIMP gene expression has been previously reported in C. gigas exposed to a mixture of eight pesticides (including diuron) at environmentally relevant concentrations over a 7-day period (Gagnaire et al. 2007). However, it is important to notice that in the present study, the effects on genes such as Mpeg1, LBP/BPI and lysozyme disappeared at $6 \mathrm{~h}$ of exposure. Similarly a down-regulation at $6 \mathrm{~h}$ was observed for MyD88 gene (0.36 \pm 0.39$)$, implicated on cell signalling (Wiens et al. 2005), but the effects disappeared at $24 \mathrm{~h}$. Thus, the results of the present study 
suggest that diuron can exert rapid effects on the expression of genes implicated in immune defence mechanisms in $C$. gigas, but also that rapid acclimatization responses can take place in the organism.

\subsection{Experiments conducted with a mixture of $5 \mu \mathrm{g}$ diuron $\mathrm{L}^{-1}, 5 \mu \mathrm{g}$ isoproturon $\mathrm{L}^{-1}$ and $5 \mu \mathrm{g}$ ibuprofen $\mathrm{L}^{-1}$}

From the different times of exposure (i.e. $0,1,3,6 \mathrm{~h}$ ), diuron mean concentration $(9.2 \pm$ $\left.0.5 \mu \mathrm{g} \mathrm{L}^{-1}\right)$ was significantly higher than isoproturon $\left(6.8 \pm 0.5 \mu \mathrm{g} \mathrm{L}^{-1}\right)$ and ibuprofen $(4.8$ $\left.\pm 0.3 \mu \mathrm{g} \mathrm{L}^{-1}\right)$ mean concentrations $(p<0.05)$. In addition, concentrations of diuron, isoproturon and ibuprofen slightly decreased during the time course of the experiment of $6 \mathrm{~h}$, but no significant differences were observed over time (data not shown).

Concerning cellular mortality, no significant differences were observed during the whole experiment (data not shown), while phagocytosis was significantly inhibited by almost $50 \%$, after $6 \mathrm{~h}$ of exposure (Fig. 3). It is important to notice also that no effect was observed in catecholase-type PO activity in the presence of diuron at $1 \mu \mathrm{g} \mathrm{L}^{-1}$, while an effect in this PO activity was observed in the presence of diuron in a mixture with another herbicide and a pharmaceutical (i.e. a significant inhibition, by $\sim 20 \%$; Fig. 3), highlighting the interest of studying the effect of single molecules but also of mixtures of contaminants that could be present at the same time in the marine environment. Furthermore, these results are in agreement with studies on the effect of herbicides on bivalves that have been carried out for longer periods of exposure and that have shown that a mixture of herbicides containing atrazine, diuron and isoproturon can diminish phagocytosis activity in C. gigas (Gagnaire et al. 2007).

\section{Conclusions}

Early effects of a single herbicide (diuron) were observed in gene expression and enzyme activities of proteins implicated in immune responses in oysters, e.g. SOD and laccase. A mix of herbicides and pharmaceuticals (diuron, isoproturon, ibuprofen) also exerted early effects on plasmatic enzyme activities and haemocytic phagocytosis activity. These results are in agreement with previous studies where short-term exposures of herbicides exerted an effect on aquatic organisms (e.g. Saglio \& Trijasse 1998, Bretaud et al. 2000), giving an insight of the potential effect of contaminants on organisms in the natural environment. An alteration in molecular, biochemical and cellular parameters could be related to the inability of the animal to manage other stressful conditions including the presence of pathogens. Therefore, coupling this type of short-term contamination approach to a pathogen challenge appears necessary (e.g. Gagnaire et al. 2007) in order to evaluate, at the physiological level, the effect of contaminants on immune defences in marine bivalves such as the Pacific oyster $C$. gigas.

\section{Acknowledgments}

This study was supported by a PhD grant from the Conseil Général de la CharenteMaritime for A. Luna-Acosta. The Conseil Régional de Poitou-Charentes is acknowledged for financial support through the research project 'POLERON' (Modifications chimiques de polluants organiques dans le bassin de Marennes-Oléron, toxicité des produits de dégradation sur l'huître creuse), N. Tapie for scientific advices 
on diuron and isoproturon analyses in water samples, and the laboratory IDHESA for diuron and DCPU analyses in water samples and oyster soft tissues.

\section{References}

Alder L, Greulich K, Kempe G, Vieth B (2006) Residue analysis of 500 high priority pesticides: Better by GC-MS or LC-MS/MS? Mass spectrom rev 25: 838-865

ASCI ENCE (2005) Aquatic Environment Monitoring Report, Centre for Environment, Fisheries and Aquaculture Science (CEFAS) Reports, $80 \mathrm{p}$

Bado-Nilles A, Renault T, Faury N, Le Floch S, Quentel C, Auffret M, Thomas-Guyon (2010) In vivo effects of LCO soluble fraction on immune-related functions and gene transcription in the Pacific oyster, Crassostrea gigas (Thunberg). Aquat Toxicol 97:196-203

Barbash J (1999) Distribution Of Major Herbicides In Ground Water Of The United States, Vol. U.S. Department of the Interior, U.S. Geological Survey, Sacramento, California, $57 \mathrm{p}$

Bocquene G, Roig A, Fournier D (1997) Cholinesterases from the common oyster (Crassostrea gigas): Evidence for the presence of a soluble acetylcholinesterase insensitive to organophosphate and carbamate inhibitors. FEBS Lett 407:261-266

Bouilly K, Bonnard M, Gagnaire B, Renault T, Lapegue S (2007) Impact of diuron on aneuploidy and hemocyte parameters in Pacific oyster, Crassostrea gigas. Arch Environ Con Tox 52:58-63

Bretaud S, Toutant JP, Saglio P (2000) Effects of carbofuran, diuron, and nicosulfuron on acetylcholinesterase activity in goldfish (Carassius auratus). Ecotox Environ Safe 47:117-124

Buisson S, Bouchart V, Guerlet E, Malas J, Costil K (2008) Level of contamination and impact of pesticides in cupped oyster, Crassostrea gigas, reared in shellfish production area in Normandy (France). J Environ Sci Heal B 43:655-664

Burgoa B, Wauchope R (1995) Pesticides In Run-Off And Surface Waters. In: Roberts $\mathrm{T}$, Kearney $\mathrm{P}$ (eds) Environmental Behaviour Of Agrochemicals. John Wiley and Sons NY, $418 p$

Cheney D, MacDonald B, Elston R (2000) Summer mortality of Pacific oysters, Crassostrea gigas (Thunberg): initial findings on multiple environmental stressors in Puget Sound, Washington. J Shellfish Res 19:353-359

Ericson H, Thorsén G, Kumblad L (2010) Physiological effects of diclofenac, ibuprofen and propranolol on Baltic Sea blue mussels. Aquat Toxicol 99:223-231

FAO (2010) Aquaculture Production: Quantities 1950-2008. Fishstat Plus

Gagnaire B, Thomas-Guyon H, Burgeot T, Renault T (2006) Pollutant effects on Pacific oyster, Crassostrea gigas (Thunberg), hemocytes: Screening of 23 molecules using flow cytometry. Cell Biol Toxicol 22:1-14

Gagnaire B, Gay M, Huvet A, Daniel J, Saulnier D, Renault T (2007) Combination of a pesticide exposure and a bacterial challenge: In vivo effects on immune response of Pacific oyster, Crassostrea gigas (Thunberg). Aquat Toxicol 84:92102

Gagne F, Blaise C, Hellou J (2004) Endocrine disruption and health effects of caged mussels, Elliptio complanata, placed downstream from a primary-treated municipal effluent plume for 1 year. Comp Biochem Phys C 138:33-44

Gagne F, Blaise C, Andre C, Salazar M (2006) Effects of pharmaceutical products and municipal wastewaters on temperature-dependent mitochondrial electron transport activity in Elliptio complanata mussels. Comp Biochem Phys C 143:388-393 
Geoffroy L, Teisseire H, Couderchet M, Vernet G (2002) Effect of oxyfluorfen and diuron alone and in mixture on antioxidative enzymes of Scenedesmus obliquus. Pestic Biochem Phys 72:178-185

Giacomazzi S, Cochet N (2004) Environmental impact of diuron transformation: A review. Chemosphere 56:1021-1032

Gramatica P, Di Guardo A (2002) Screening of pesticides for environmental partitioning tendency. Chemosphere 47:947-956

Heberer T (2002) Occurrence, fate, and removal of pharmaceutical residues in the aquatic environment: A review of recent research data. Toxicol Lett 131:5-17

Johnston SA (1981) Estuarine dredge and fill activities: A review of impacts. Environ Manage 5:427-440

Luna-Acosta A, Rosenfeld E, Amari M, Fruitier-Arnaudin I, Bustamante P, ThomasGuyon H (2010) First evidence of laccase activity in the Pacific oyster Crassostrea gigas. Fish Shellfish Immun 28:719-726

Mah SA, Moy GW, Swanson WJ, Vacquier VD (2004) A perforin-like protein from a marine mollusk. Biochem Bioph Res Co 316:468-475

Mitta G, Galinier R, Tisseyre P, Allienne JF, Girerd-Chambaz Y, Guillou F, Bouchut A, Coustau C (2005) Gene discovery and expression analysis of immune-relevant genes from Biomphalaria glabrata hemocytes. Dev Comp Immunol 29:393-407

Munaron D (2004) Study Of Herbicides And Nutrients Inputs By The Charente River To The Coast And Modelling Of The Dispersion Of Atrazine In The MarennesOléron Bay. Université Pierre et Marie Curie Paris V, $341 \mathrm{p}$

Perdue J, Beattie J, Chew K (1981) Some relationships between gametogenic cycle and summer mortality phenomenon in the Pacific oyster (Crassostrea gigas) in Washington State. J Shellfish Res 1:9-16

Pesce S, Margoum C, Montuelle B (2010) In situ relationship between spatio-temporal variations in diuron concentrations and phototrophic biofilm tolerance in a contaminated river. Water Res 44:1941-1949

Pfaffl MW (2001) A new mathematical model for relative quantification in real-time RTPCR. Nucleic Acids Res 29:e45

Powell, E.N., Hofmann, E.E., Klinck, J.M., Ray, S.M., 1992. Modeling oyster populations I. A commentary on filtration rate. Is faster always better? J. Shellfish Res. 11, 387-398.

Rabiet M, Togola A, Brissaud F, Seidel JL, Budzinski H, Elbaz-Poulichet F (2006) Consequences of treated water recycling as regards pharmaceuticals and drugs in surface and ground waters of a medium-sized Mediterranean catchment. Environ Sci Technol 40:5282-5288

Saglio P, Trijasse S (1998) Behavioral responses to atrazine and diuron in goldfish. Arch Environ Con Tox 35:484-491

Samain J, Degremont L, Soletchnik P, Haure J, Bedier E, Ropert M, Moal J, Huvet A, Bacca H, Van Wormhoudt A, Delaporte M, K, Pouvreau S, Lambert C, Boulo V, Soudant P, Nicolas J, Le Roux F, Renault T, Gagnaire B, Geret F, Boutet I, Bourgeaot T, Boudry P (2007) Genetically based resistance to summer mortality in the Pacific oyster (Crassostrea gigas) and its relationship with physiological, immunological characteristics and infection processes. Aquaculture 268:227-243

Shankar MV, Nélieu S, Kerhoas L, Einhorn J (2008) Natural sunlight -induced photodegradation of phenylurea herbicides in water. Chemosphere 71:1461-1468

Smith P, Khron R, Hermanson G, Mallia A, Gartner F, Provanzano M, Fujimoto E, Goeke N, Olson B, Goeke N, Olson B, Klenk D (1985) Measurement of a protein using bicinchoninic acid. Anal Biochem 150:76-85

Söderhäll K, Cerenius L (1998) Role of the prophenoloxidase-activating system in invertebrate immunity. Curr Opin Immunol 10:23-28 
Tanguy A, Boutet I, Laroche J, Moraga D (2005) Molecular identification and expression study of differentially regulated genes in the Pacific oyster Crassostrea gigas in response to pesticide exposure. FEBS J 272:390-403

Therond P, Gerbaud P, Dimon S, Anderson WB, Evain-Brion D, Raynaud F (1996) Antioxidant enzymes in psoriatic fibroblasts and erythrocytes. JInvest Dermatol 106:1325-1331

Thomas K, Fileman T, Readman J, Waldock M (2001) Antifouling paint booster biocides in the UK coastal environment and potential risks of biological effects. Mar Pollut Bull 42:677-688

Togola A, Budzinski H (2008) Multi-residue analysis of pharmaceutical compounds in aqueous samples. J Chromatogr A 1177:150-158

Wiens M, Korzhev M, Krasko A, Thakur N, Perovic-Ottstadt S, Breter H, Ushijima H, Diehl-Seifert B, Müller I, Müller W (2005) Innate immune defense of the sponge Suberites domuncula against bacteria involves a MyD88-dependent signaling pathway. Induction of a perforin-like molecule. J Biol Chem 280:27949-27959

Zar J (1984) Biostatistical Analysis, Prentice-Hall, New Jersey, 736 p

Figures

Figure 1. Effect of diuron $\left(1 \mu \mathrm{g} \mathrm{L}^{-1}\right)$ on enzymatic activities $\left(\mathrm{U} \mathrm{mg} \mathrm{prot}^{-1}\right)$ in the Pacific oyster Crassostrea gigas. a: laccase-type phenoloxidase and b: superoxide dismutase activities. White bars correspond to the control and black bars correspond to the treatment condition. Mean $\pm S D, n=6$ ( 3 replicates of 2 pools of 20 oysters), $N=2$ experiment replicates. * Statistical difference between control and treatment at each time with $p<0.05$.

a

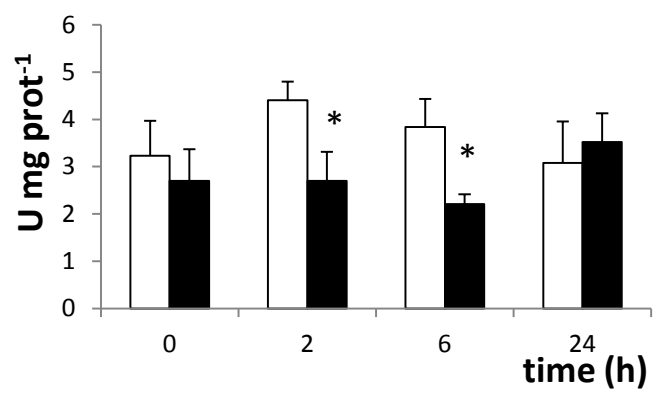

b

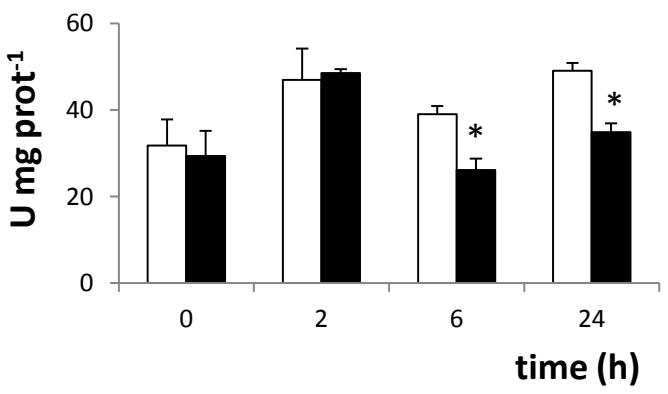


Figure 2. Effect of diuron $\left(1 \mu \mathrm{g} \mathrm{L}^{-1}\right)$ on gene expression ( $\mathrm{U}$ relative mRNA expression ratio) in the Pacific oyster Crassostrea gigas. Results are expressed as relative expression to the control of each time. Control values were represented by the dotted line located at 1 relative expression of transcripts. Mean $\pm S D, n=6$ (3 replicates of 2 pools of 20 oysters), $\mathrm{N}=2$ experiment replicates. Mpeg1: macrophage expressed protein 1-like; MyD88: myeloid differentiation factor; SOD: superoxide dismutase; LBP/BPI: lipopolysaccharide-binding protein/mammalian bactericidal/permeabilityincreasing protein; TMP: tissue inhibitor of metalloproteinases. Statistical difference between control and treatment at each time with ${ }^{*} p<0.05,{ }^{* *} p<0.01,{ }^{* * *} p<0.001$.

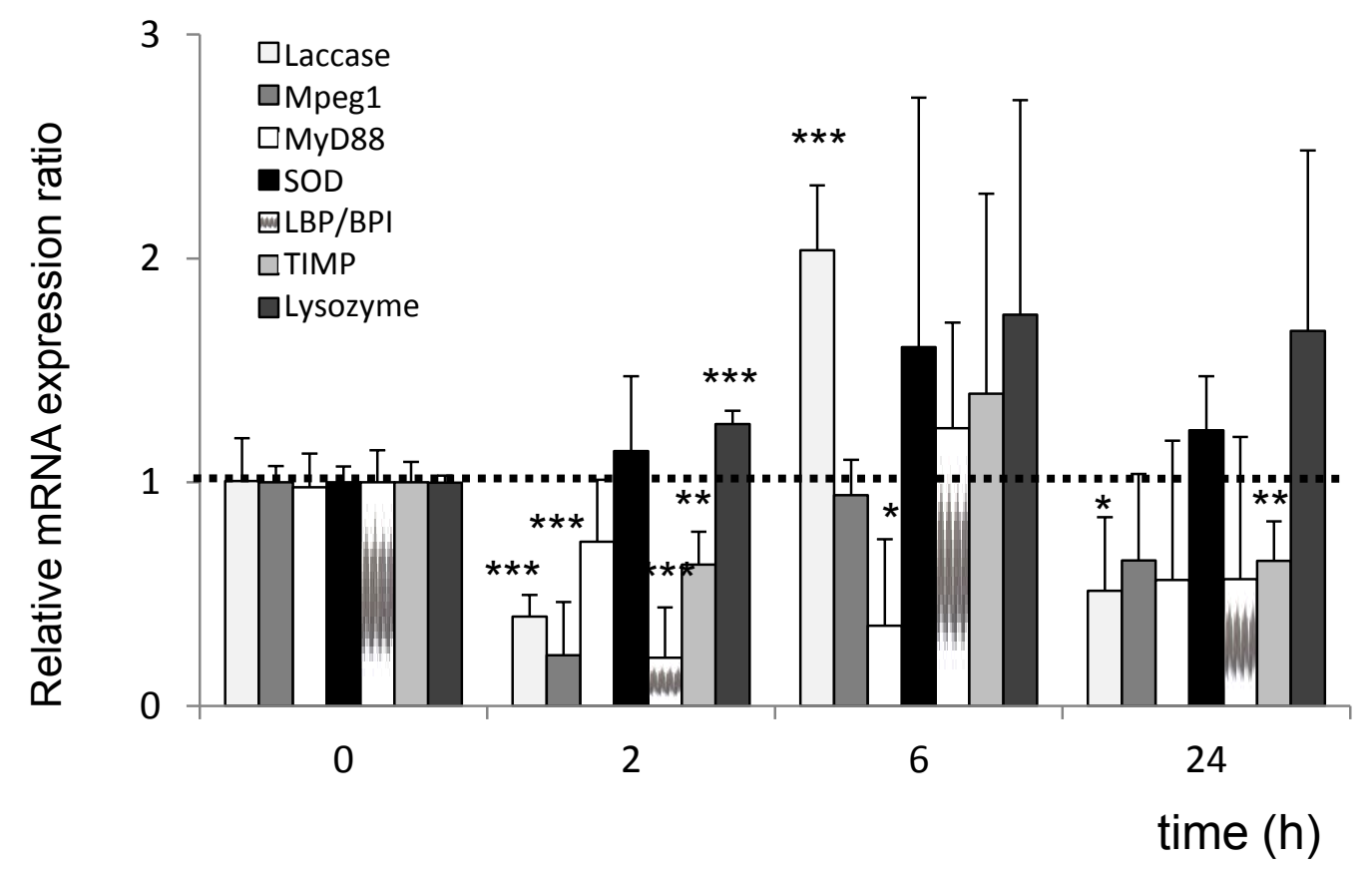

Figure 3. Effect of a mixture of herbicides (diuron at $5 \mu \mathrm{g} \mathrm{L}^{-1}$, isoproturon at $5 \mu \mathrm{g} \mathrm{L}^{-1}$ ) and pharmaceuticals (ibuprofen at $5 \mathrm{mg} \mathrm{L}^{-1}$ ) on (a) phagocytosis (in \%) in the haemolymph and (b) catecholase-type phenoloxidase activity (in $U \mathrm{mg}$ prot $^{-1}$ ) in the plasma of the Pacific oyster Crassostrea gigas. White bars correspond to the control and black bars correspond to the treatment condition. Mean \pm SD; $n=12$ (3 replicates of 4 pools of 20 oysters), $N=4$ experiment replicates. ${ }^{*}$ Statistical difference between control and treatment at each time with $p<0.05$.

a

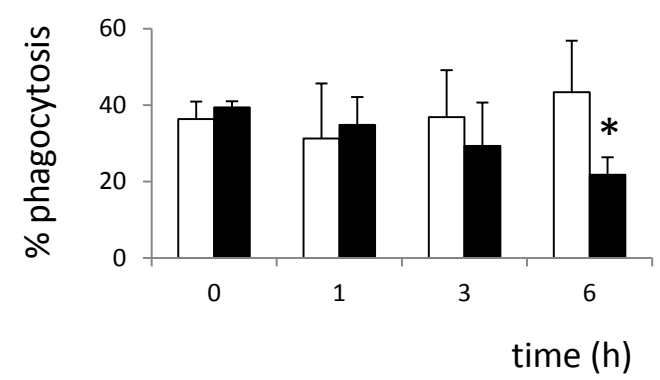

b

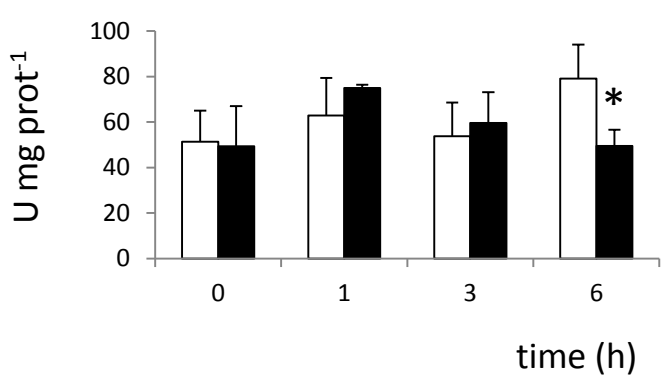




\section{Tables}

Table 1. Diuron content in seawater and oyster soft tissues in the experiment with diuron (at $\left.1 \mu \mathrm{g} \mathrm{L}^{-1}\right)$. NA: not analysed.

\begin{tabular}{|c|c|c|c|c|c|}
\hline \multirow[t]{2}{*}{ Sample } & \multirow[t]{2}{*}{ Parameter } & \multicolumn{4}{|c|}{ Time (h) } \\
\hline & & 0 & 2 & 6 & 24 \\
\hline \multirow{2}{*}{ Seawater } & Diuron concentration $\left(\mu \mathrm{g} \mathrm{L}^{-1}\right)$ & 0.8 & NA & NA & 0.6 \\
\hline & Quantity of diuron per tank $(\mu \mathrm{g})$ & 28.7 & NA & NA & 22.6 \\
\hline \multirow[t]{6}{*}{ Oyster } & Diuron concentration $\left(\mu \mathrm{g} \cdot \mathrm{kg}^{-1}\right)$ & $<0.2$ & 9.2 & 9.8 & 10.8 \\
\hline & DCPU concentration $\left(\mu \mathrm{g} \cdot \mathrm{kg}^{-1}\right)$ & $<0.2$ & $<0.2$ & $<0.2$ & $<0.2$ \\
\hline & Quantity of diuron per oyster $(\mu \mathrm{g})$ & $<0.2$ & 0.014 & 0.015 & 0.016 \\
\hline & $\mathrm{BCF}\left(\mathrm{L} \mathrm{kg}^{-1}\right)^{*}$ & NA & NA & NA & 16.7 \\
\hline & Theoretical FR $\left(\text { L oyster }^{-1} \mathrm{~h}^{-1}\right)^{\dagger}$ & \multicolumn{4}{|l|}{1.4} \\
\hline & $\begin{array}{l}\text { Mean dry weight of soft tissue ( } \mathrm{g} \\
\text { oyster }^{-1} \text { ) }\end{array}$ & \multicolumn{4}{|c|}{$1.5 \pm 0.2$} \\
\hline
\end{tabular}

*BCF: The bioconcentration factor corresponds to the ratio: oyster diuron concentration/seawater diuron concentration.

${ }^{\dagger}$ Theoretical FR: The theoretical filtration rate was calculated with the formula of Powell et al (1992): $\mathrm{FR}=\left(\mathrm{SL}^{0.96} \times \mathrm{T}^{0.95}\right) / 2.95$, where $\mathrm{FR}$ is the filtration rate $(\mathrm{mL}$ filtered per oyster and per min), $S L$ (in $\mathrm{cm}$ ) is shell length and $\mathrm{T}$ is temperature (in ${ }^{\circ} \mathrm{C}$ ). Then our result was expressed in $L$ filtered per oyster and per hour. 